Article

\title{
Arable Podzols are a substantial carbon sink under current and future climate: evidence from a long-term experiment in Vladimir region, Russia
}

\author{
Igor Ilichev ${ }^{1}$, Vladimir Romanenkov ${ }^{1,2}$, Sergei Lukin ${ }^{3}$, Vera Pavlova ${ }^{4}$, Stanislav Siptits ${ }^{5}$ and Pavel \\ Krasilnikov ${ }^{1, *}$ \\ 1 Faculty of Soil Science, Lomonosov Moscow State University, 119991 Moscow; Russian Federation; \\ igor.ilichev.msu@gmail.com \\ 2 Geographical Network Department, All-Russian Research Institute of Agrochemistry named after \\ D. Pryanishnikov, 127550 Moscow; Russian Federation; romanenkov@soil.msu.ru \\ 3 All-Russian Research Institute of Organic Fertilizers and Peat, branch of Upper Volga Federal Agrarian \\ Scientific Center, 601390, Vyatkino, Vladimir Region, Russian Federation; vnion@vtsnet.ru \\ 4 National Research Institute of Agricultural Meteorology, 249030 Obninsk, Russia; vnp2003@bk.ru \\ 5 All-Russian Institute of Agrarian Problems and Informatics named after A. Nikonov, 105064 Moscow; \\ Russian Federation; siptits@mail.ru \\ * Correspondence: krasilnikov@soil.msu.ru
}

\begin{abstract}
Soil organic carbon (SOC) is an essential condition for soil health and a potential sink for greenhouse gases. SOC dynamics in a long-term field experiment with mineral and organic fertilization on loamy sand Podzol in Vladimir Region, Russia, was traced with the dynamic carbon model RothC since 1968 until the present time. During this period, C stock increased 21\% compared with the initial level in the treatment with the application of manure in an average annual rate of 10 t $\cdot$ ha $\mathrm{a}^{-1}$. The model was also used to forecast SOC changes until 2090 for two contrasting RCP4.5 and RCP8.5 climatic scenarios. Until 2090, the steady growth of SOC stocks is expected in all compared treatments for both climate scenarios. This rate of growth was the highest until 2040, decreased in 2040-2070 and increased again in 2070-2090 for RCP4.5. The highest annual gain was within 21-27\%o under RCP4.5 and 16-21\%o in 2020-2040 in 0-20 cm soil layer. The expected accumulation of C allows increasing current $C$ stock 1.6-1.7 times for RCP4.5 and 2.0-2.2 times for RCP8.5 scenario. Modelling demonstrated potentially more favourable conditions for SOC stability in arable Podzols than in Retisols in Central Russia in the 21st century.
\end{abstract}

Keywords: soil organic carbon; soil health; long-term experiments; RothC model; climate change; "4 per 1000" initiative; Podzols

\section{Introduction}

Agricultural soils represent a promising opportunity to manage $C$ stocks. The interest in developing strategies for soil organic carbon (SOC) sequestration is related to the fact that this process can achieve significant reductions in greenhouse gas emissions by providing a level of $\mathrm{CO}_{2}$ in the atmosphere that prevents an increase in the global average temperature of more than $2^{\circ} \mathrm{C}$. In recent years, a large number of studies have focused on $\mathrm{C}$ storage and reducing its losses by optimizing agricultural management. Increasing the $C$ stock in arable land soils improves soil health and the environment, so it is recognized as a "win-win strategy" [1]. Alternative farming methods have been tested in many countries to use their potential to optimize carbon and nitrogen cycles in agroecosystems [2]. 
C sequestration by arable soils allows considering them as a significant resource in climate change mitigation at a low cost and implement soil managing techniques aimed at SOC sequestration on a global scale. As a practical development of this concept, the "4 per 1000" initiative was put forward at the COP 21 of the UNFCCC. According to this initiative, an annual increase in carbon reserves in all soils used in agriculture by $0.4 \%$ in the $0-40 \mathrm{~cm}$ layer will double the reduction of greenhouse gas emissions into the atmosphere [3]. However, there are quite a lot of questions about the practical feasibility of such a process for agricultural soils. This process is quite challenging to control with high reserves of soil $\mathrm{C}$ and strongly depends on changes in agricultural technology. Also, the accumulation of $C$ in the soil is finite, usually coming to an equilibrium state within 20-30 years. It is subject to external factors that change the productivity of the agroecosystems, such as climate change, and is related to the issue of sustainable agriculture. Finally, its implementation can be challenging from an economic point of view, so careful selection of climate-smart agricultural soils is required [4].

In this regard, long-term field experiments are a suitable experimental base for practical testing of the approaches to SOC sequestration, allowing integrated use of long-term data on weather conditions, crop productivity, and agricultural technology features, including fertilizer systems as the most frequently studied active factor in the experiments. Many existing meta-analyses of $\mathrm{C}$ sequestration on a global and regional scale are based on the generalization of data from long-term field experiments [5-8]. Since only a few of these experiments were specifically designed to evaluate the dynamics of $\mathrm{C}$, their value increases when integrated with carbon dynamics models. The comparative analysis of various experimental variants complemented by modelling allows us to identify alternative solutions for the use of various agrotechnological techniques that provide $\mathrm{C}$ sequestration.

We already tested the results of field experiments of the "Geographical experimental network for the use of fertilizers" for practical testing of the agrotechnology's suitability for reaching the goals of the "4 per 1000" initiative [9-11]. In this paper, we assess the potential of carbon sequestration by arable sandy Podzols, which are believed to have a high potential for $C$ sequestration [12]. We provide analysis for current and future climate conditions to develop optimal agricultural techniques for increasing SOC reserves by more than $4 \%$ o per annum.

\section{Materials and Methods}

For the present study, we used the data obtained in a long-term field experiment of the Research Institute of Organic Fertilizers and Peat "The effect of long-term application of fertilizer systems on the productivity of grain crop rotation, product quality and fertility of sod-podzolic soil", which initiated in 1968 and lasted for 50 years. The experimental field is located in the North-Eastern part of the Meshcherskaya lowland, $10 \mathrm{~km}$ from the city of Vladimir near the village of Vyatkino in Sudogodsky district $\left(56^{\circ} 04^{\prime} 01^{\prime \prime} \mathrm{N}, 40^{\circ} 29^{\prime} 09^{\prime \prime} \mathrm{E}\right)$. The climate is temperate continental without a dry season and with warm summer (Dfb), the average air temperature for the year is $3.9^{\circ} \mathrm{C}$, the sum of biologically active temperatures $\left(>10^{\circ} \mathrm{C}\right)$ is $2000-2100^{\circ} \mathrm{C}$, the annual precipitation is $560-590 \mathrm{~mm}$. According to geobotanical zoning, the territory of the farm is located in the southern taiga subzone with a predominance of mixed coniferous and deciduous forests. In geomorphological terms, this area is lacustrine-glacial zander, slightly undulating lowland. Absolute altitude ranges from 130 to $170 \mathrm{~m}$ above sea level. Soil parent material texture is sand to sandy loam in places underlain by loamy moraine till. A characteristic feature of light-textured soils under natural vegetation in the region is the low content of organic matter and nutrition elements, low cation exchange capacity, and high acidity. Ploughing results in the formation of a 20-25-centimeter arable layer. This layer contains more organic carbon and nutrition elements, slightly heavier texture and more expressed structure that leads to higher biological activity and biodiversity and thus reflects better soil health. The soil of the particular experimental field had a sandy loam texture, underlain on the depth $40-50 \mathrm{~cm}$ by loamy moraine till. In the international classification, the soil is classified as Albic Podzol (Epiarenic, Endoloamic, Aric, Raptic) [13]. Soil properties before establishing the experiment were as follows: $\mathrm{pH}$ 6.2-6.5, extractable acidity - 1.0-2.2 $\mathrm{cmolc}^{\cdot} \mathrm{kg}^{-1}$, exchangeable bases $-4.8-5.3 \mathrm{cmolc}^{\circ} \mathrm{kg}^{-1}$, labile $\mathrm{P}_{2} \mathrm{O}_{5}-14-$ $25 \mathrm{mg} \cdot \mathrm{kg}^{-1}$ (very low availability), $\mathrm{K}_{2} \mathrm{O}-63-104 \mathrm{mg} \cdot \mathrm{kg}^{-1}$ (low to medium availability). The clay content 
at $0-20 \mathrm{~cm}$ was $80 \mathrm{~g} \cdot \mathrm{kg}^{-1}$, the initial reserve of SOC was $11.0 \mathrm{t} \cdot \mathrm{ha}^{-1}$. The site has been used in agriculture for at least 200 years. Experimental data on productivity dynamics, agrochemical indicators, and organic $C$ in the long-term experiment are summarized in the work of Lukin et al. [14].

The long-term experiment was established to study the effect of long-term use of various fertilizer systems (organic, organo-mineral and mineral) on crop rotation productivity and fertility of arable Podzols. The study aimed to explore the balance and transformation of organic matter and elements of mineral nutrition of plants. The scheme of the experiment includes options without fertilizers (absolute control) and options with a different combination of mineral and organic fertilizers (organo-mineral), as well as options with their separate application. Crop rotation included annual lupine-winter wheat-potatoes-barley on two fields with four replications. The size of plots was $7 \mathrm{~m} \times 23 \mathrm{~m}=161 \mathrm{~m}^{2}$ with the total area of the experiment 2.6 ha. The most dramatic changes in the main agrochemical indicators occurred during the first 2-3 rotations. Then they varied following the annual intake of nutrients with fertilizers, their removal by the crop and their fixation in the soil. In 1984-1989, the experiment was mothballed, with the passage of a two-year fallow field during this period. Since 1989, fertilization and crop rotation have been resumed according to the previous scheme. Currently, data on 11 crop rotation rotations are summarized.

To model the dynamics of soil organic matter, we used data on four variants for 1968-1998: control; NPK ( $\mathrm{N}_{50} \mathrm{P}_{25} \mathrm{~K}_{60}$ equivalent to $10 \mathrm{t}^{\mathrm{h}} \mathrm{ha}^{-1}$ manure annually); a half dose of mineral and organic fertilizers -5 tha ${ }^{-1}$ of farmyard manure (FYM) $+\mathrm{N}_{25} \mathrm{P}_{12} \mathrm{~K}_{30}(1 / 2 \mathrm{FYM}+1 / 2 \mathrm{NPK})$; manure and a double dose of mineral fertilizers $-10 \mathrm{t}^{\mathrm{h}} \mathrm{h}^{-1} \mathrm{FYM}+\mathrm{N}_{100} \mathrm{P}_{50} \mathrm{~K}_{120}$ (FYM+2NPK). Table 1 shows the dynamics of crop rotation productivity for the selected options, taking into account by-products.

Table 1. The productivity of grain crop for the rotation, 1968-2018, centner of grain units per hectare

\begin{tabular}{lccccccccccc}
\hline \multirow{2}{*}{ Variant } & \multicolumn{10}{c}{ Crop rotations } \\
\cline { 2 - 11 } & I & II & III & IV & V & VI & VII & VIII & IX & X & XI \\
\hline Control & 30.3 & 26.1 & 24.9 & 18.9 & 28.5 & 22.6 & 16.3 & 23.3 & 21.3 & 14.5 & 18.9 \\
1/2FYM+ & & & & & & & & & & & \\
$1 / 2 \mathrm{NPK}$ & 40.0 & 37.9 & 36.6 & 31.7 & 37.8 & 38.1 & 24.9 & 36.7 & 38.8 & 27.5 & 30.8 \\
NPK & 38.3 & 32.1 & 37.2 & 34.3 & 39.9 & 38.4 & 24.3 & 41.3 & 36.5 & 27.9 & 34.0 \\
FYM+ & & & & & & & & & & & \\
$2 \mathrm{NPK}$ & 42.6 & 41.2 & 44.7 & 34.6 & 46.1 & 47.2 & 29.5 & 49.1 & 50.3 & 36.7 & 32.5 \\
\hline
\end{tabular}

It was found that acidification of the soil occurred after 11 rotations. The most significant decrease in $\mathrm{pH}$ was observed in the variants with the introduction of mineral fertilizers (Table 2). The content of mobile phosphorus in the soil without the use of fertilizers practically did not change in comparison with the initial one. Despite the annual removal of phosphorus with the crops, the content of mobile phosphorus in the soil was stabilized at the level of $51 \mathrm{mg} \cdot \mathrm{kg}^{-1}$ (medium availability) when fertilizer of $25 \mathrm{~kg} \cdot \mathrm{ha}^{-1}$ of $\mathrm{P}_{2} \mathrm{O}_{5}$ was applied. When applying higher doses $\left(\mathrm{P}_{50}\right)$, the phosphorus content in the soil increased. Long-term use of arable soil without applying potash fertilizers led to a decrease in the potassium content. The highest potassium content at the end of the 11th rotation -246 $\mathrm{mg} \cdot \mathrm{kg}^{-1}$ (very high availability) - was observed when applying manure at a dose of $10 \mathrm{t}^{\mathrm{t}} \mathrm{ha}^{-1}$ together with mineral fertilizers $\mathrm{N}_{100} \mathrm{R}_{50} \mathrm{~K}_{120}$ (Table 2). 
Table 2. Agrochemical characteristics of the soil at the end of the 11th grain crop rotation, 2018

\begin{tabular}{|c|c|c|c|c|c|c|}
\hline \multirow[b]{2}{*}{ Variant } & \multirow[t]{2}{*}{ рНксІ } & \multirow{2}{*}{$\begin{array}{l}\text { Extractable } \\
\text { acidity } \\
\mathrm{cmolc}^{\prime} \cdot \mathrm{kg}^{-1}\end{array}$} & $\mathrm{P}_{2} \mathrm{O}_{5}$ & $\mathrm{~K}_{2} \mathrm{O}$ & \multirow{2}{*}{$\begin{array}{c}\text { Bases } \\
\mathrm{cmolc} \cdot \mathrm{kg}^{-1}\end{array}$} & \multirow{2}{*}{$\begin{array}{c}\mathrm{C} \\
\mathrm{g} \cdot \mathrm{kg}^{-1}\end{array}$} \\
\hline & & & \multicolumn{2}{|c|}{$\begin{array}{c}0.2 \mathrm{M} \mathrm{HCl} \\
\text { extraction, } \\
\mathrm{mg} \cdot \mathrm{kg}^{-1}\end{array}$} & & \\
\hline Control & 5.48 & 1.35 & 28 & 93 & 4.76 & 5.28 \\
\hline 1/2FYM+1/2NPK & 5.47 & 1.5 & 51 & 142 & 5.08 & 6.03 \\
\hline NPK & 5.36 & 1.57 & 57 & 150 & 4.91 & 6.21 \\
\hline FYM+2NPK & 5.27 & 1.6 & 156 & 246 & 4.28 & 7.25 \\
\hline
\end{tabular}

To study the dynamics of soil organic carbon, we used the RothC version 26.3 model, which examines the cycle of organic matter in the arable layer of automorphic mineral soils. It uses a monthly step, taking into account the influence of soil type, temperature, soil humidity, and vegetation cover [15]. In the RothC model, ORP is divided into five pools: carbon of readily decomposing plant residues DPM, stable plant material RPM, microbial biomass BIO, humified HUM, and inert IOM organic matter, which have different mineralization rates described by first-order equations. The amount of $C$ monthly entering the soil was calculated using the Levin dependence [16] and reference data on the quality of FYM. The initial distribution of carbon across these pools to run the model is modelled for equilibrium $\mathrm{C}$ content conditions. The content of the IOM pool, according to [17] was pre-calculated at 1.19 tha $^{-1}$. After calculating the IOM pool, the RothC model was run in the mode of calculating the distribution of $C$ across the pools by selecting the average long-term value of $C$ input to the soil so that the $C$ stock obtained by modelling corresponded to the experimentally determined one. The calculated equilibrium average annual value of $C$ input was $500 \mathrm{~kg} \cdot \mathrm{ha}^{-1}$. A control variant was used to configure the model, and the data from the other variants were considered independent to check the quality of the configuration. Verification of the correspondence of experimental and calculated data was carried out based on the Modeval model for statistical evaluation of simulation results [18].

The forecast of the dynamics of SOC reserves under the future climate was made for the climate scenarios RCP4.5 and RCP8.5 used in the IPCC AR5 report. These scenarios describe four pathways of changes in greenhouse gas emissions and concentrations as well as in land-use for the 21st century [19]. The scenarios RCP4.5 corresponds to the moderate anthropogenic impact on the Earth's climate system and scenario RCP8.5 - to the extreme effects. $\mathrm{CO}_{2}$ concentrations forecast by 2100 for RCP4.5 is 580-650 ppm $\mathrm{CO}_{2}$ and more than $1000 \mathrm{ppm}$ for the RCP8.5 scenario. Regional climate model developed at the Voeikov Main Geophysical Observatory for an ensemble scenario of 31 CMIP5 models [20] was used for calculations of climate data for the experimental area basing on the "Climate-SoilYield" simulation system [21]. The output data were temperature, precipitation, and potential evapotranspiration with a monthly resolution up to 2100 . The obtained climate data were used to make a forecast of crop rotation yield for each treatment until 2090. Additional details are described in Prokopyeva et al. [22].

\section{Results}

Figures 1 and 2 show the dynamics of carbon input into the soil both with plant residues (crop residues + underground biomass, Figure 1) and in total, taking into account the introduction of carbon with organic fertilizers (Figure 2). In general, the entire observation period can be divided into two sections: the period before the conservation of the experiment (1968-1986) and the period from the renewal of the experiment to the present (1990-2017). 


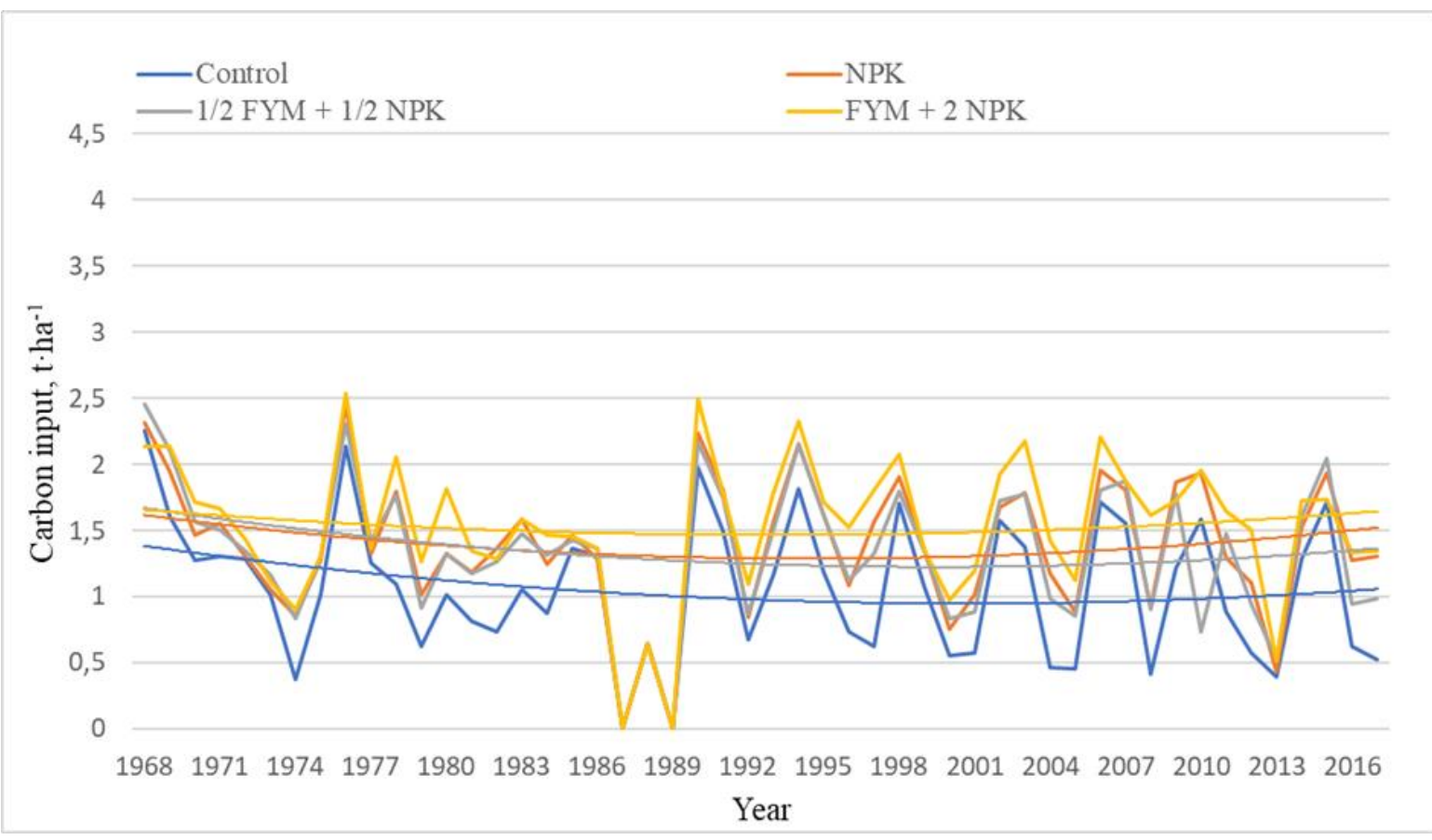

Figure 1. The annual $\mathrm{C}$ input in the long-term field experiment with plant residues. On the axis of abscissas the year of input, on the axis of ordinate - the input according to crop-specific biomass allocation coefficients of organic $\mathrm{C}$ with stubble and belowground biomass. Smoothing was done with second-degree polynomials.

In the period before conservation, there is a decrease in the supply of carbon with plant residues in all four variants (Fig. 1). After the resumption of the experiment, the $\mathrm{C}$ flow stabilized: the variants of NPK, and 1/2FYM+1/2NPK at the level of $1200-1300 \mathrm{~kg} \cdot \mathrm{ha}^{-1}$ per year, the option FYM+2NPK $1500 \mathrm{~kg} \cdot \mathrm{ha}^{-1}$ per year, while in control, the indicator dropped below the mark of $1000 \mathrm{~kg} \cdot \mathrm{ha}^{-1}$ per year and stabilized at $950 \mathrm{~kg} \cdot \mathrm{ha}^{-1}$ per year. After a period of stabilization, its growth resumed, more noticeable in the last 15 years of the experiment, in the variants with fertilization. It should also be noted that in the control case, there was a slight increase in $C$ input at the end of the observation period. The difference in the dynamics of $\mathrm{C}$ input in control and the variants with fertilizers was primarily due to the relatively smaller amount of plant residues, which can also be traced by the dynamics of crop rotation productivity (Table 1). Also, a smaller ratio of underground and aboveground products in the total biomass, which is taken into account in the Levin equations [16], contributed to this difference. Differences in crop rotation productivity between the variants with organic and mineral fertilizers significantly affected the receipt of plant residues only after the conservation of the experiment. The average intake of $C$ was close for the NPK and 1/2FYM+1/2NPK

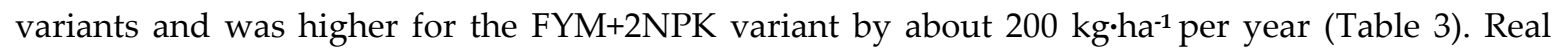
changes were caused by the intake of $C$ with organic fertilizers applied regularly every two years, as can be seen from Figure 2. Additional carbon input from the biannual application of organic fertilizers to the soil resulted in an average increase of about $200 \mathrm{~kg} \cdot \mathrm{ha}^{-1}$ per year for the option $1 / 2 \mathrm{FYM}+1 / 2 \mathrm{NPK}$ (extra 13\%) and about $600 \mathrm{~kg} \cdot \mathrm{ha}^{-1}$ per year (extra 28\%) for the option FYM+2NPK (Table 3). 


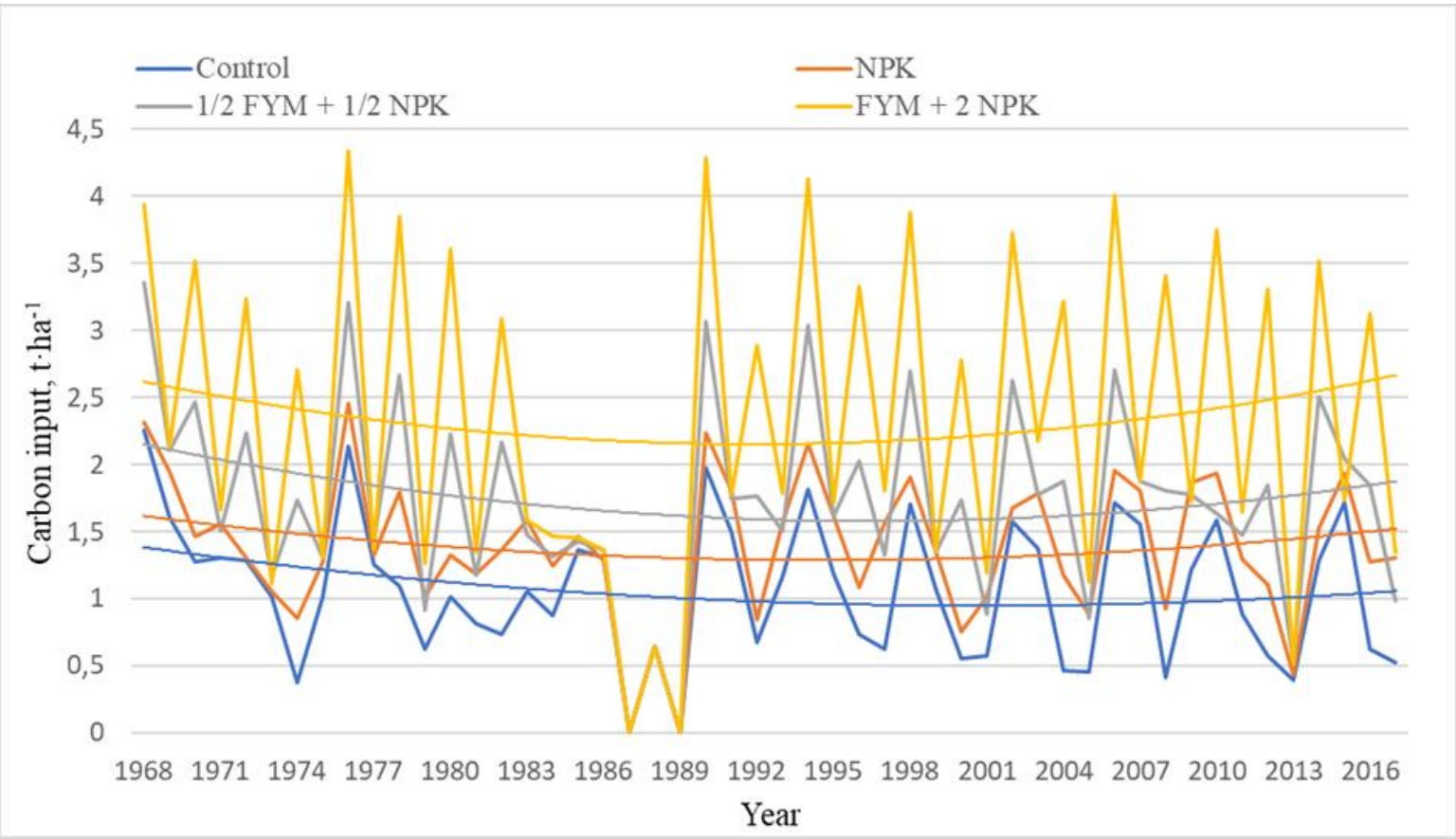

Figure 2. The annual $\mathrm{C}$ input in the long-term field experiment in total, with plant residues and organic fertilizers. On the axis of abscissas - the year of input, on the axis of ordinate - the total input of organic C. Smoothing was done with second-degree polynomials.

Table 3. Indicators of organic carbon balance in a long-term experiment (1968-2017)

\begin{tabular}{|c|c|c|c|c|}
\hline \multirow[t]{2}{*}{ Mean annual value, $t \cdot h^{-1}$} & \multicolumn{4}{|c|}{ Variants } \\
\hline & Control & NPK & 1/2FYM+1/2NPK & FYM+2NPK \\
\hline $\mathrm{C}$ input with plant residues, & 1.06 & 1.39 & 1.34 & 1.55 \\
\hline experimental, 1968-2017 & & & $(87 \%)$ & $(72 \%)$ \\
\hline C input with organic fertilizers, & - & - & 0.20 & 0.59 \\
\hline experimental, 1968-2017 & & & $(13 \%)$ & $(28 \%)$ \\
\hline$\Delta C, 0-20 \mathrm{~cm}$ layer, model, $1968-2017$ & -0.092 & -0.024 & 0.004 & 0.087 \\
\hline $\mathrm{C}-\mathrm{CO}_{2}$ flux to the atmosphere, model & 1.156 & 1.418 & 1.540 & 1.872 \\
\hline
\end{tabular}

With a drop in the total average annual C input over the period 1968-1983 for organo-mineral variants, the period 1975-1984 was more favourable for crop development compared to the beginning of the experiment (1968-1974). This phenomenon led to a slight slowdown in the rate of $C$ drop. When the experiment was resumed in 1990, the increase in C input to the soil decreased in the series FYM+2NPK $>1 / 2$ FYM+1/2NPK $>$ NPK. Notably, the stabilization and beginning of the C input growth were observed in the FYM+2NPK variant earlier than in the $1 / 2 \mathrm{FYM}+1 / 2 \mathrm{NPK}$ variant.

Considering the dynamics of the total C stock in the soil over the entire study period (Fig. 3), we can see that the behaviour of the dynamics of the total stock as a whole correlated with changes in the supply of carbon to the soil. 


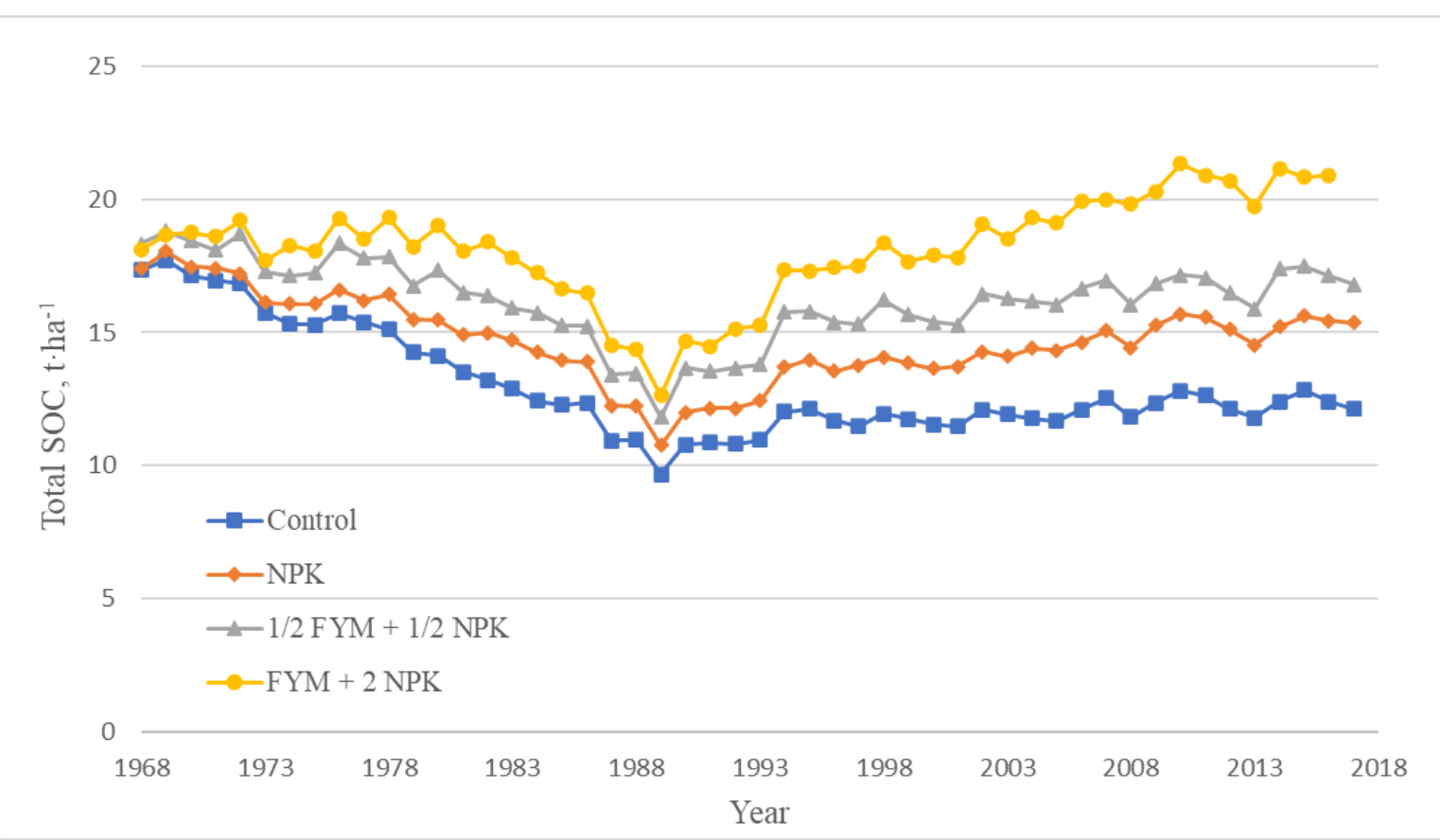

Figure 3. Simulated changes in total organic C stock in the long-term experiment for the period in 1968-2017 based on SOC stock at the end of each calendar year.

Over the entire period of the experiment, the FYM+2NPK variant accumulated $3.6 \mathrm{t} \cdot \mathrm{ha}^{-1}$ of manure $(21.3 \%$ of the initial content). For the $1 / 2 \mathrm{FYM}+1 / 2 \mathrm{NPK}$ variant, SOC was able to reach the initial reserves. In the variant NPK, by 2017 , the observed loss of carbon stock was $-1,57$ tha $^{-1}(9.3 \%$ of the initial content) and in the control $-4,81 \mathrm{t} \cdot \mathrm{ha}^{-1}$ (28,4\% of the original content). Most of the C stock loss in all variants occurred before conservation. During this period, the loss of $C$ stock occurred in all variants, increasing in the series: control $>$ NPK $>1 / 2 \mathrm{FYM}+1 / 2 \mathrm{NPK}>\mathrm{FYM}+2 \mathrm{NPK}$ and amounted to -7.25 tha ${ }^{-1}(42.8 \%),-6.17$ tha- $\mathrm{a}^{-1}(36.5 \%)-5.1 \mathrm{t} \cdot \mathrm{ha}^{-1}(30.1 \%)$ and $-4.29 \mathrm{t} \cdot \mathrm{ha}^{-1}(25.4 \%)$, respectively.

Since the launch of the experiment in 1990, all variants except the control have shown a steady increase in the total C stock. SOC reserves reached a plateau in the second half of the period, around 2005 in the NPK and 1/2FYM+1/2NPK variants and about 2010 in the FYM+2NPK variant. The largest increase was observed in the FYM+2NPK variant. After reaching the minimum values during the conservation period $\left(12.6 \mathrm{t}^{-} \cdot \mathrm{ha}^{-1}\right)$, the total carbon stock increased to $20.5 \mathrm{t} \cdot \mathrm{ha} \mathrm{A}^{-1}(63 \%)$ by 2017. In the variant $1 / 2 \mathrm{FYM}+1 / 2 \mathrm{NPK}$, the minimum stock was $11.8 \mathrm{t}^{\mathrm{k}} \mathrm{ha}^{-1}$, after which by 2017 it increased to 16.8 $\mathrm{t} \cdot \mathrm{ha}^{-1} \mathrm{C}(42.4 \%)$. For the NPK variant, the stock rose from $10.8 \mathrm{t} \cdot \mathrm{ha}^{-1}$ to $15.4 \mathrm{t} \cdot \mathrm{ha}^{-1} \mathrm{C}(42.6 \%)$ during this period. The rapid growth of the indicator is primarily due to significant losses of $\mathrm{C}$ reserves both in the period before conservation and especially during the conservation itself, which included twoyear fallow. The $C$ stock in the control version of the experiment after reaching the minimum level during conservation had a small increase in the first years after renewal, after which it reached a plateau with a stable reserve of about $12 \mathrm{t} \cdot \mathrm{ha}^{-1} \mathrm{C}$. In the variants with fertilization, the output to the plateau occurred around 2008, ranging from 15 to $21 \mathrm{t} \cdot \mathrm{ha}^{-1} \mathrm{C}$.

The average annual losses of $\mathrm{C}$ to the atmosphere in the form of $\mathrm{CO}_{2}$ in the course of mineralization of plant residues, organic matter, and organic fertilizers were calculated using the RothC model. These losses averaged 1,156 kg:ha-1 for the control variant, increasing to 1,418 kg.ha-1 for NPK, 1,540 kg.ha-1 for 1/2FYM+1/2NPK, and 1,872 kg.ha-1 for FYM+2NPK, and a total of 56.6, 69.4, 75.4, and $91.7 \mathrm{t} \cdot \mathrm{ha}^{-1}$, respectively, for 49 years (Table 3 ).

Comparison of model data on the dynamics of total SOC stocks with experimental data showed that the model satisfactorily reproduced the observed dynamics of SOC stocks (Fig. 4, Table 4). 


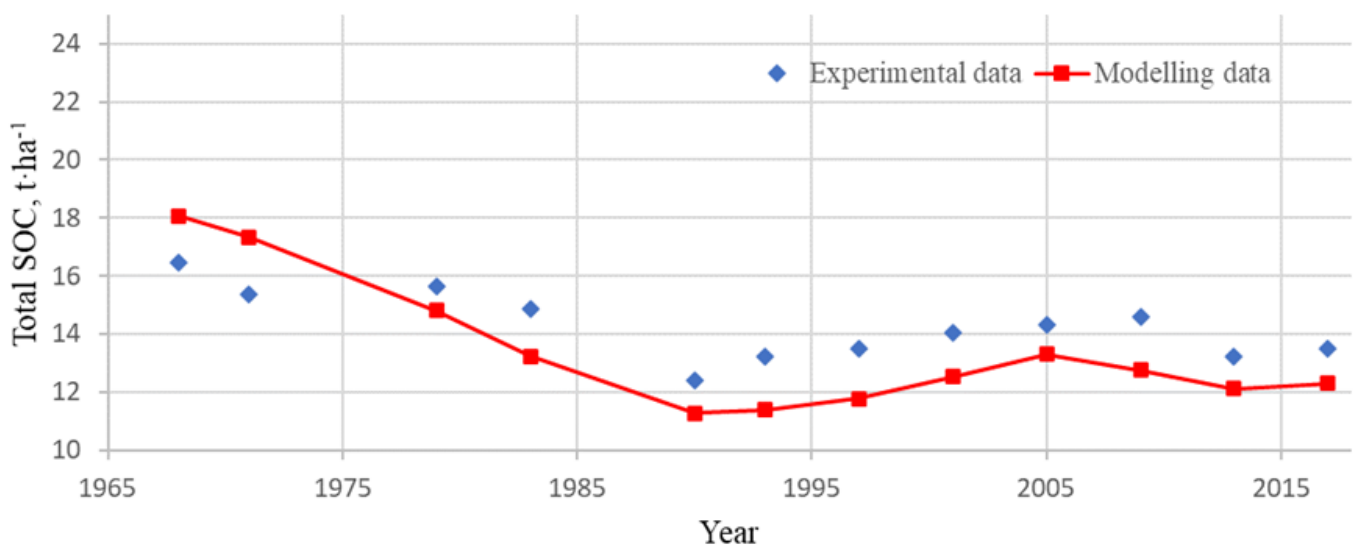

$\mathbf{a}$

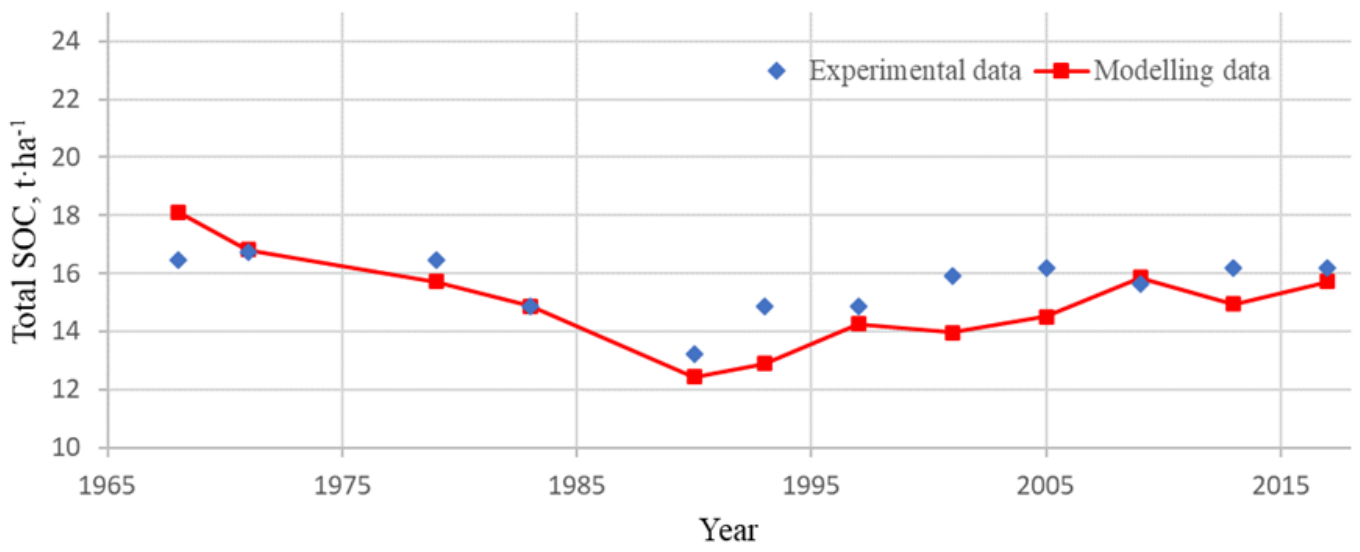

b

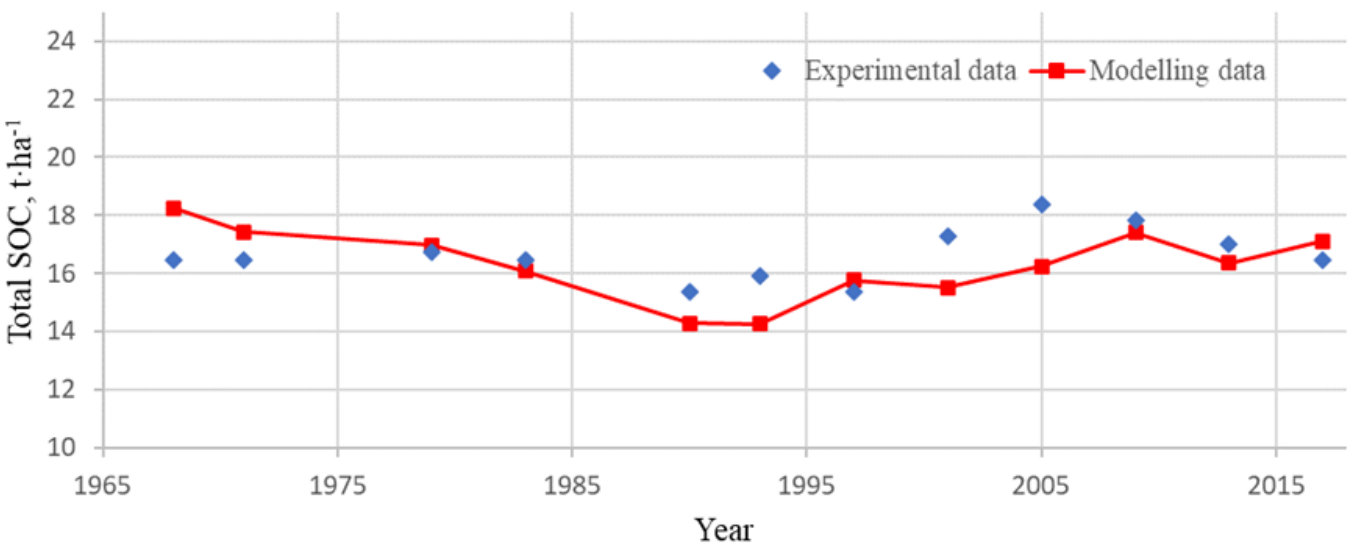

c

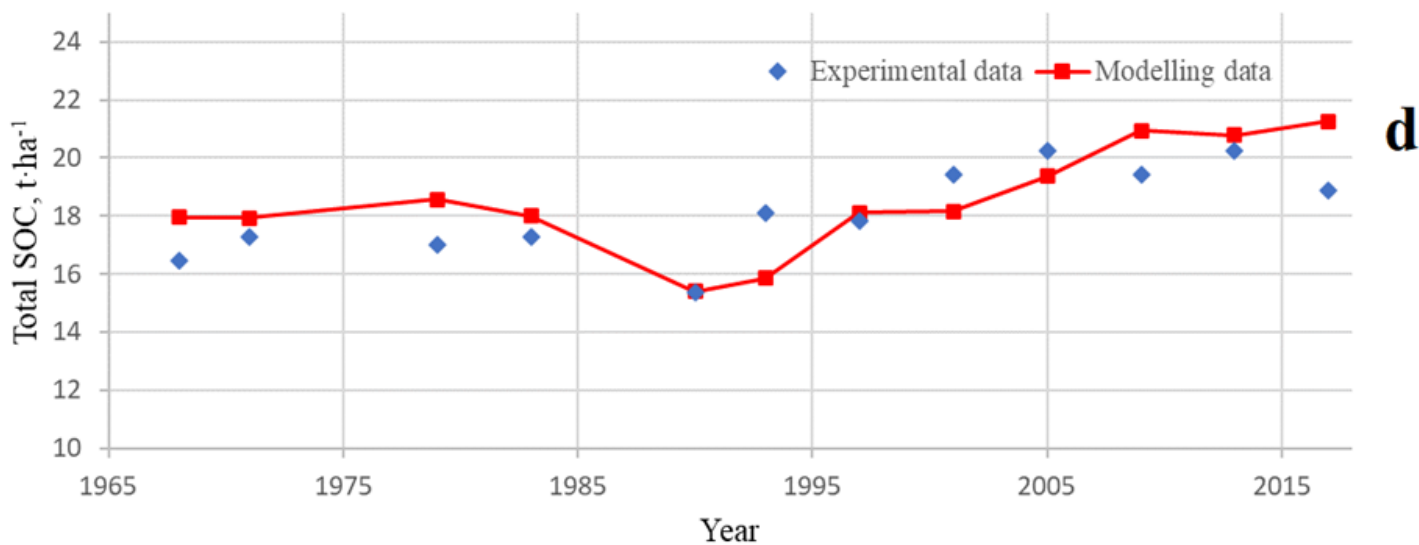

Figure 4. Experimentally determined (dots) and calculated (lines) by RothC SOC stocks in a 0-20 cm soil layer of a long-term experiment in the period 1968-2017 for four treatments: a - control, b - NPK, c $-1 / 2 \mathrm{FYM}+1 / 2 \mathrm{NPK}$, d - FYM +2 NPK 
At the same time, there was some underestimation of the results in the post-conservation period 1990-2010, since the observed growth of C stocks was faster than predicted by the model. However, in the initial period of modelling on the FYM+2NPK variant, there was an overestimation of the results. The values of the correlation coefficient varied in the range of 0.4-0.9; the lowest value of the average square error -7.2 was observed in the variant 1/2FYM+1/2NPK, but in all cases, it did not exceed 10.5. The determination index for all variants was $0.3-0.7$, which indicated the possibility of a more significant deviation of the simulated values from the observed average, compared to the experimental data.

Table 4. Comparison of simulated and calculated data on the dynamics of $\mathrm{C}$ reserves $\left(\mathrm{t} \cdot \mathrm{ha}^{-1}\right)$ for four variants of long-term experiment and statistical evaluation of modelling. RMSE-root-mean-square error, EF - simulation efficiency, CD - coefficient of determination, M - mean difference, based on Smith et al. [18]

\begin{tabular}{|c|c|c|c|c|c|c|c|c|}
\hline \multirow[t]{2}{*}{ Year } & \multicolumn{2}{|c|}{ Control } & \multicolumn{2}{|c|}{ NPK } & \multicolumn{2}{|c|}{ 1/2 NPK + 1/2 FYM } & \multicolumn{2}{|c|}{2 NPK + FYM } \\
\hline & Measured & Predicted & Measured & Predicted & Measured & Predicted & Measured & Predicted \\
\hline 1968 & 16,47 & 18,08 & 16,47 & 18,12 & 16,47 & 18,25 & 16,47 & 17,97 \\
\hline 1971 & 15,39 & 17,34 & 16,74 & 16,82 & 16,47 & 17,44 & 17,28 & 17,94 \\
\hline 1979 & 15,66 & 14,81 & 16,47 & 15,73 & 16,74 & 16,97 & 17,01 & 18,58 \\
\hline 1983 & 14,85 & 13,25 & 14,85 & 14,88 & 16,47 & 16,08 & 17,28 & 18,00 \\
\hline 1990 & 12,42 & 11,29 & 13,23 & 12,45 & 15,39 & 14,29 & 15,39 & 15,40 \\
\hline 1993 & 13,23 & 11,40 & 14,85 & 12,90 & 15,93 & 14,27 & 18,09 & 15,85 \\
\hline 1997 & 13,5 & 11,77 & 14,85 & 14,27 & 15,39 & 15,78 & 17,82 & 18,12 \\
\hline 2001 & 14,04 & 12,53 & 15,93 & 13,98 & 17,28 & 15,51 & 19,44 & 18,15 \\
\hline 2005 & 14,31 & 13,30 & 16,2 & 14,52 & 18,36 & 16,24 & 20,25 & 19,38 \\
\hline 2009 & 14,58 & 12,75 & 15,66 & 15,85 & 17,82 & 17,41 & 19,44 & 20,93 \\
\hline 2013 & 13,23 & 12,12 & 16,2 & 14,94 & 17,01 & 16,37 & 20,25 & 20,78 \\
\hline 2017 & 13,5 & 12,31 & 16,2 & 15,73 & 16,47 & 17,11 & 18,9 & 21,27 \\
\hline \multicolumn{9}{|c|}{ Statistical performance } \\
\hline RMSE & 10,43 & & 7,5 & & 7,16 & & 7,34 & \\
\hline EF & $-0,74$ & & $-0,46$ & & $-0,97$ & & 0,18 & \\
\hline $\mathrm{CD}$ & 0,24 & & $-0,97$ & & 0,48 & & 0,67 & \\
\hline M & 0,85 & & 0,18 & & 0,34 & & $-0,4$ & \\
\hline
\end{tabular}

The average annual value of the change in soil reserves in the arable layer calculated by RothC, depending on The $\mathrm{C}$ input, is described by a linear relationship on average throughout observations of Cinp:

$$
\Delta C=0,201 \operatorname{Cinp}-303,94
$$

Where $\Delta C$ is the average annual change in $C$ reserves in the $0-20 \mathrm{~cm}$ layer, $\mathrm{kg} \cdot \mathrm{ha}^{-1}$.

According to this dependence, to maintain SOC stocks we should apply an annual average of $1,515 \mathrm{~kg}$, and to accumulate annually $4 \%-1,853 \mathrm{~kg} \mathrm{C}$. As can be seen from Table 3 , the first condition is met in the variant $1 / 2 \mathrm{FYM}+1 / 2 \mathrm{NPK}$, and the second in the variant FYM+2NPK.

The change in soil reserves in the arable layer depending on the input of $C$, based on experimental observations for the same period, is better described by a logarithmic relationship:

$$
\Delta C=173,7 \ln (\operatorname{Cinp})-1268,1
$$

According to the above relationship, to maintain C reserves in the soil, an average of $1,483 \mathrm{~kg}$ of $\mathrm{C}$ must be applied annually, which is close to the calculated model. 

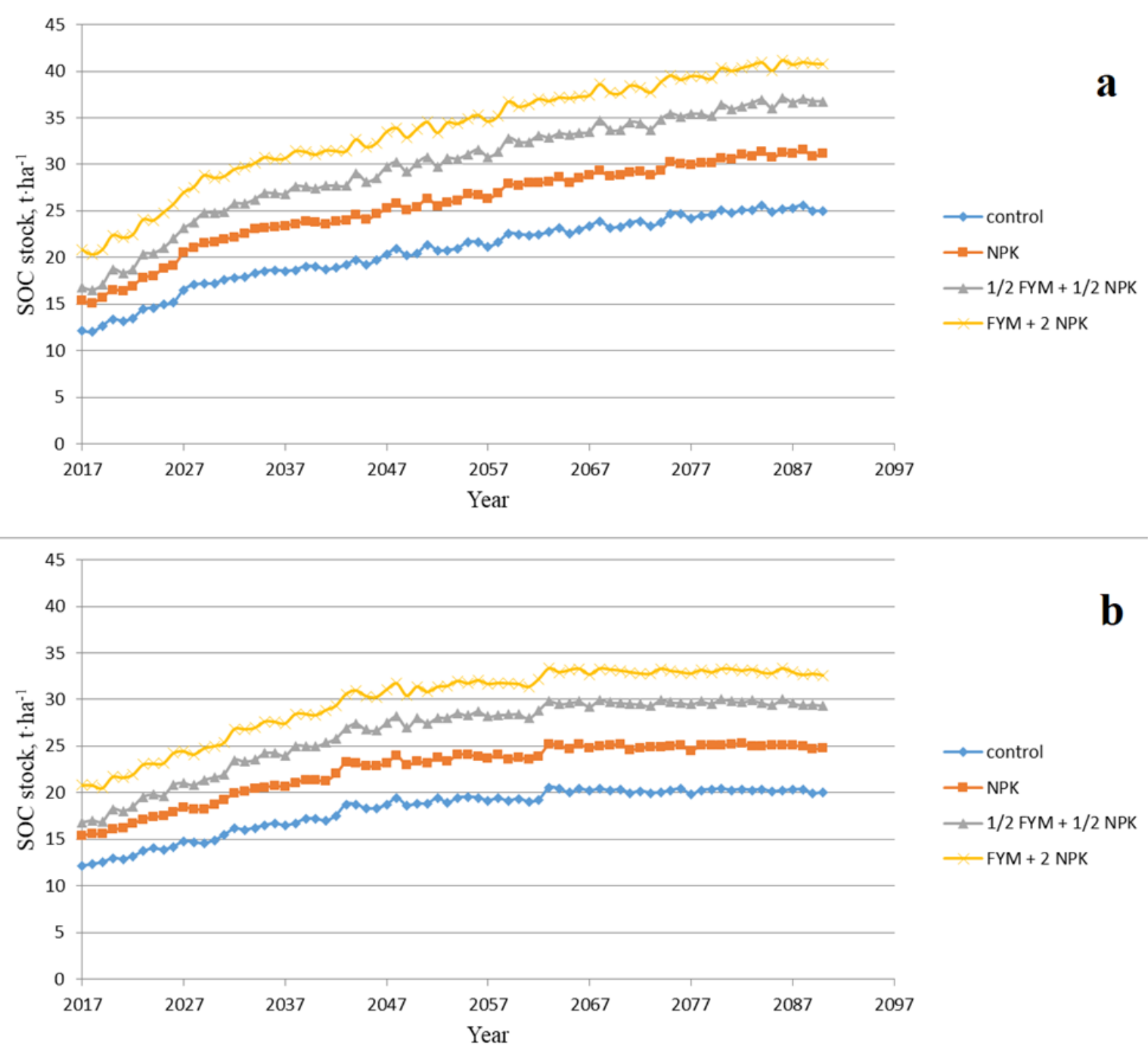

Figure 5. The dynamics of total SOC stocks predicted by the RothC model for 2017-2090 under the RCP4.5 (a) and RCP8.5 (b) climate scenarios.

Figure 5 shows calculated data on the dynamics of carbon in the soils of the studied long-term experiment variants in the period 2017-2090 for both climate scenarios. With climate change under the RCP4.5 scenario, $C$ stock increases over the entire period, while under the RCP8.5 scenario, the $C$ stock reaches a plateau by 2070 for all the compared variants. Thus, under the less severe climate change scenario RCP4.5, by taking measures to limit greenhouse gas emissions, additional opportunities exist for carbon deposition by arable soils in the period 2070-2090.

Compared to 2018, the RCP4.5 scenario assumes an increase in the soil C stock by $12.9 \mathrm{t} \cdot \mathrm{ha}^{-1}$ for the control variant, by $15.8 \mathrm{t} \cdot \mathrm{ha}^{-1}$ for the NPK variant, and by $20.0 \mathrm{t} \cdot \mathrm{ha}^{-1}$ for the organo-mineral variants. If the RCP8.5 scenario is implemented, the increase in $\mathrm{C}$ reserves will be smaller and will amount to $7.9 \mathrm{t}^{\mathrm{t}} \mathrm{ha}^{-1}$ for the control variant, $9.5 \mathrm{t} \cdot \mathrm{ha}^{-1}$ for the NPK variant, $12.6 \mathrm{t} \cdot \mathrm{ha}^{-1}$ for 1/2FYM+1/2NPK, and $11.8 \mathrm{t} \cdot \mathrm{ha}^{-1}$ for the FYM+2NPK variant. For both scenarios, an increase in organic $C$ reserves in the period 2017-2090 is expected in the series: 1/2FYM+1/2NPK > FYM+2NPK > NPK > control.

To estimate the annual increase and loss of C, we divided the modelling period from 1968 to 2090 into five periods, from 20 to 30 years each. The use of twenty-year periods is recommended following the 4 per 1000 calculation approaches discussed [23,24] (Table 5).

In the period 2018-2090, an increase in SOC is projected to be 1.3-1.5 times under the RCP4.5 scenario and $13-20 \%$ less over the same periods under the RCP 8.5 scenario (Table 5). This result can provide an annual increase in $C$ reserves from $21-27 \%$ under the first and $16-21 \%$ o under the second climate scenario in 2020-2040. In the period 2040-2070, although C input will remain at the same level 
(RCP 4.5) or slightly increase (RCP8.5), it is expected to accumulate only 7 and 5-6\%o, respectively. In the last 20 years, the increase in SOC under the RCP4.5 scenario will decrease by half. Under the RCP8.5 scenario, a loss of up to $1 \%$ of previously accumulated reserves may be expected. At the same time, the input of $C$ will not decrease under both scenarios. The accumulation rate is predicted to be the highest for the variant $1 / 2 \mathrm{FYM}+1 / 2 \mathrm{NPK}$ and the lowest for the variant FYM+2NPK. This trend reflects the finiteness of sequestration processes with an increase in $C$ input to the soil when a new equilibrium state is reached. The variant FYM+2NPK at the beginning of the modelled period has the largest $C$ reserve that most probably would lead to a lower $C$ stocks growth rate even amid higher income in the soil.

Table 5. Annual gain/loss and input of C in the variants of the experiment, 1968-2019

\begin{tabular}{lllll}
\hline Period & \multicolumn{4}{c}{ Annual gain/loss, \%o / C input, tha- ${ }^{-1}$} \\
\hline & Control & NPK & 1/2FYM+1/2NPK & FYM+2NPK \\
\hline 1968-1986 & $-14.21 / 1.18$ & $-9.44 / 1.47$ & $-5.26 / 1.67$ & $-1.39 / 1.86$ \\
1990-2017 & $-0.12 / 1.07$ & $4.74 / 1.46$ & $4.41 / 1.59$ & $10.39 / 2.02$ \\
RCP4.5 scenario & & & & \\
2018-2040 & $24.72 / 1.41$ & $23.70 / 1.81$ & $27.39 / 2.13$ & $21.34 / 2.60$ \\
2041-2070 & $7.32 / 1.43$ & $6.97 / 1.79$ & $7.44 / 2.11$ & $6.83 / 2.60$ \\
2070 - 2090 & $3.51 / 1.50$ & $3.86 / 1.88$ & $4.36 / 2.22$ & $4.02 / 2.71$ \\
RCP8.5 scenario & & & & \\
2018-2040 & $18.31 / 1.17$ & $17.02 / 1.50$ & $21.15 / 1.82$ & $15.62 / 2.24$ \\
2041-2070 & $5.84 / 1.28$ & $5.78 / 1.60$ & $6.07 / 1.92$ & $5.47 / 2.38$ \\
2070 - 2090 & $-0.63 / 1.30$ & $-0.76 / 1.54$ & $-0.50 / 1.84$ & $-0.75 / 2.40$ \\
\hline
\end{tabular}

Figure 6 shows an estimate of the possible accumulation of $C$ under the future climate. The accumulation of $C$ is approximately equal for two organo-mineral variants for the period 2018-2070 under the RCP4.5 scenario. If the RCP8.5 scenario is implemented, the $1 / 2 \mathrm{FYM}+1 / 2 \mathrm{NPK}$ variant is slightly better. In the period 2070-2090, the mineral variant provides an additional accumulation of about $2 \mathrm{t} \cdot \mathrm{ha}^{-1} \mathrm{C}$, and the organo-mineral ones $-3 \mathrm{t} \cdot \mathrm{ha}^{-1}$ under the RCP4.5 scenario.

\section{Discussion}

The long-term experimental studies with an application of the RothC model are interesting from several points of view. First, these studies demonstrate the practical possibility of managing organic $C$ reserves in the arable soil layer using simple crop rotation. With small natural reserves of organic $\mathrm{C}$, the soil shows a rapid response to the variation in both crop rotation productivity, which leads to a traceable accumulation of $C$ reserves, and the possibility of rapid loss of previously accumulated $C$ in the course of conservation period. For example, for the control variant, the model predicts the loss of up to $40 \%$ of the initial $\mathrm{C}$ reserves during the two-year fallow period. Possible significant loss - up to $60 \%$ of reserves, previously accumulated by a Podzol under a 200 -year-old pine forest in Scotland, was shown using the RothC 26.3 simulation [25]. 

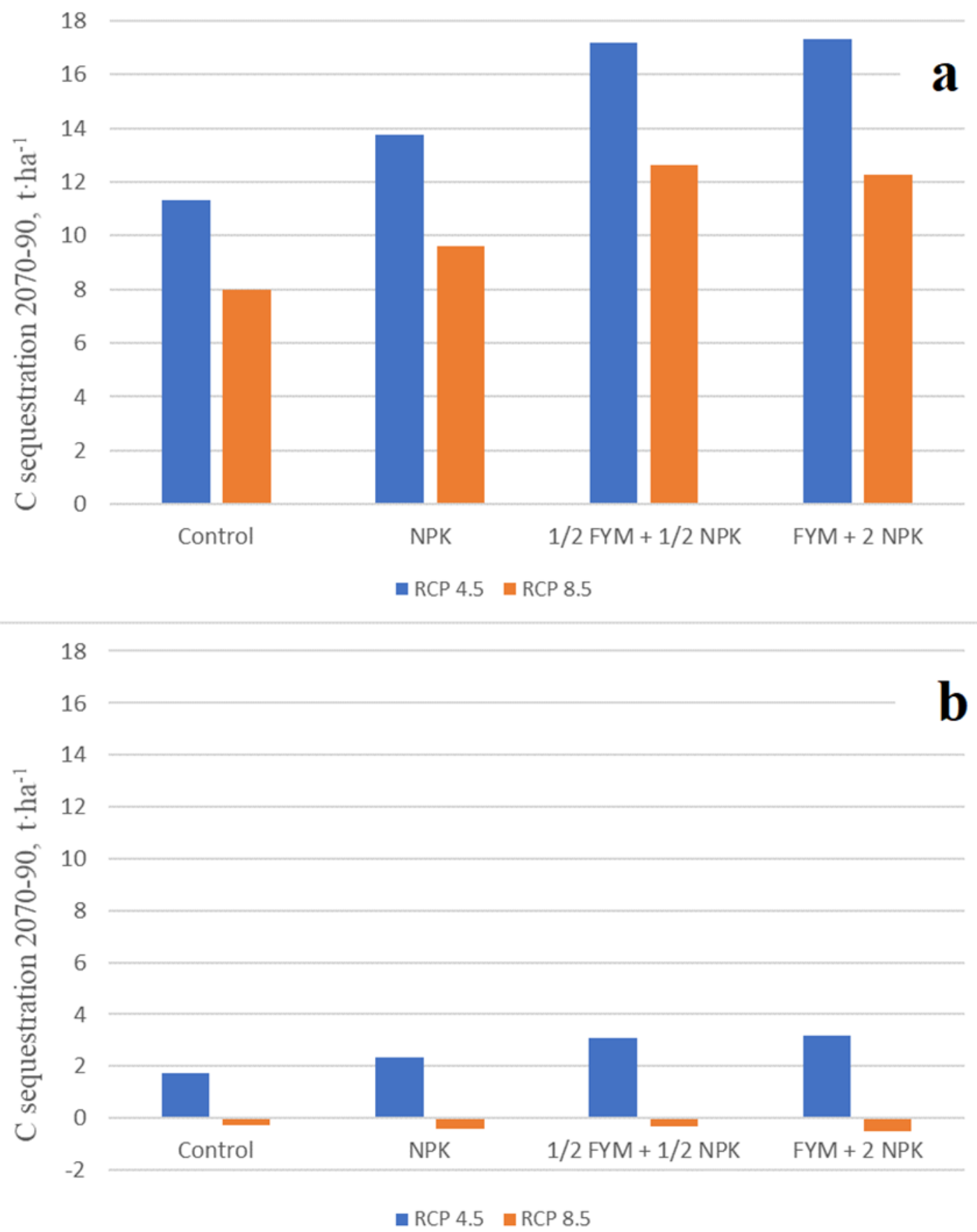

Figure 6. Simulated soil carbon sequestration under future climatic scenarios RCP4.5 and RCP8.5 between 2018 and 2070 (a) and 2070-90 (b) for the different treatments.

A noteworthy positive result is the ability of Podzol to maintain the initial SOC reserves at an annual intake of $1.5 \mathrm{t} \cdot \mathrm{ha}^{-1}$ of $\mathrm{C}$ and the sequential accumulation of $4 \%$ at an additional input of 350 $\mathrm{kg} \cdot \mathrm{ha}^{-1}$ of $\mathrm{C}$. These trends are practically traced for 30 years after the conservation of the experiment and are reproduced using RothC. As shown earlier, for Retisols of different texture for the same cool temperature zone with initial C stock $19-32 \mathrm{t} \cdot \mathrm{ha}^{-1} \mathrm{C}$ input $1.5 \mathrm{t} \cdot \mathrm{ha}^{-1} \cdot \mathrm{yr}^{-1}$ was needed, but $\mathrm{C}$ input was estimated as high as $2.0 \mathrm{t} \cdot \mathrm{ha}^{-1} \cdot \mathrm{yr}^{-1}$ for maintaining sustainable C stock $41-43 \mathrm{t} \cdot \mathrm{ha}^{-1}$ [12]. These estimates are less than those given in Wang et al. [26], which estimated the critical C input rate for arable soils to produce wheat in Russia as $1.9 \mathrm{t} \cdot \mathrm{ha}^{-1} \cdot \mathrm{yr}^{-1}$ with current average and potential inputs 1.3 and 2.8 $\mathrm{t} \cdot \mathrm{ha}^{-1} \cdot \mathrm{yr}^{-1}$, respectively. This value probably applies primarily to Chernozem soils with large absolute reserves of organic C. Previously we demonstrated by modelling using RothC 26.3 based on a long- 
term field experiment on Chernozem that to maintain or increase organic $C$ reserves, it is necessary to ensure the introduction of at least $1900-2100 \mathrm{~kg} \cdot \mathrm{ha}^{-1} \mathrm{C}$ [10].

The second important conclusion is the possibility of more favourable conditions for sequestration with the studied soil in the future climate. During the experiment in 1968-2018, SOC reserves reached the initial value only in the FYM+2NPK variant. Under the future environment (RCP4.5 climate scenario), the initial SOC stock may be achieved in the control variant by 2042, in the NPK variant - by 2026 , and in the $1 / 2 \mathrm{FYM}+1 / 2 \mathrm{NPK}$ variant - by 2023 . For the RCP 8.5 scenario, this level will be reached in 2051, 2030, and 2023, respectively. The accumulation of $C$ implies further growth, which can meet the condition for all variants that repeatedly exceed $4 \%$ in the first 20 years and then practically meets this condition in the next 30 years - until 2070 for the RCP4.5 scenario. In this case, we take into account that the 4 per 1000 initiative considers a layer of $0-40 \mathrm{~cm}$, so the absolute increase only in the upper horizon should be higher than $4 \%$. According to [27] long-term Rothamsted experiments with fertilizers, it was proposed to use a value $>7 \%$ in the $0-23 \mathrm{~cm}$ layer as equivalent to $4 \%$ in the upper $40 \mathrm{~cm}$ layer.

When modelling the dynamics of $\mathrm{C}$ in a long-term experiment in the Moscow region on Retisol, we showed that while it is challenging to ensure yield growth for the RCP4.5 scenario and especially RCP8.5, the condition determining the possibility of additional sequestration of $\mathrm{C}$ is a decrease in the critical level of annual $C$ input to the soil $[11,22]$. At the same time, the expected growth is provided only in the period 2020-2040.

In the current long-term experiment, the existing crop rotation allows both a steady increase in productivity under the future climate and a consistent increase in C stocks. The latter can be traced over 50 years with a gradual decrease in the sequestration rate for the RCP4.5 scenario or reaching a new equilibrium level after 2060 for the RCP8.5 scenario. This fact allows considering light-textured arable soils in the non-Chernozem zone, especially in the context of the loss of part of the initial reserves of $C$, as a suitable object for the implementation of the 4 per 1000 initiative in the long term. The results obtained are much more optimistic compared to the data provided by Weismeirer et al. [28] for agricultural soils in Bavaria. According to the most optimistic scenario of these authors for the 21st century if the $C$ supply will increase by $20 \%$, the soil will lose $3-8 \%$ of the current $C$ supply, and to maintain the current SOC level, an increase in the C supply of at least $29 \%$ is necessary.

According to the equation (1), the proportion of $C$ accumulated in the soil is 0.2 of the total mass of the introduced carbon, which is consistent with the data of Grant et al. [29]. This value is higher than 0.095 for the control variant and 0.14 for the NPK variant reported by Ludwig et al. [30], obtained in the long-term experiment "Eternal rye" in Halle on sandy Haplic Phaeozem. Currently, in order to maintain the initial reserves of $C$ in the control variant, it is necessary to additionally provide an annual supply of $450 \mathrm{~kg} \cdot \mathrm{ha}^{-1}$ of C (Table 3). In the expected climate conditions

The calculations also allow us assessing the possibility for long-term maintenance of organic carbon reserves and the required crop rotation productivity. From the model data, it is clear that in order to maintain the initial reserves of $C$ in the control variant, it is necessary to additionally provide an annual supply of $450 \mathrm{~kg} \cdot \mathrm{ha}^{-1}$ of C (Table 3). According to the results shown in Table 5, it can be seen that in 2020-2040, the increase in C reserves is more than $18 \%$ with an increase in revenue from less than $100 \mathrm{~kg} \cdot \mathrm{ha}^{-1}$. However, from Fig. 6 and Table 5 it can be seen that the additional annual intake of $500 \mathrm{~kg} \cdot \mathrm{ha}^{-1}$ of $C$ in the variant FYM+2NPK compared to the variant $1 / 2 \mathrm{FYM}+1 / 2 \mathrm{NPK}$ does not provide further $\mathrm{C}$ accumulation over a 50 -year period, which reflects the finality of the soil capacity for $C$ sequestration.

\section{Conclusions}

The study of the possibility of long-term $C$ sequestration by sandy Podzols in the Vladimir Meshchera region with an initially low content of organic matter using the RothC dynamic modelling showed that combined use of organic and mineral fertilizers allows SOC accumulation of more than $10 \%$ over 30 years. At the same time, to maintain the initial reserves of organic $C$, an average annual intake of $1.5 \mathrm{t}^{\mathrm{h}} \mathrm{ha}^{-1}$ is required, and to accumulate at least $4 \%$ in the arable layer $-1.8 \mathrm{t} \cdot \mathrm{ha}^{-1}$. The described system has a significant disequilibrium, which causes a rapid change in $C$ stocks depending 
on the dynamics of crop rotation productivity. Under the expected climate in the $21^{\text {st }}$ century, the $C$ input will increase 1.3-1.5 times under the RCP4.5 scenario and decrease 13-20\% for the same periods under the RCP 8.5 scenario. With a decrease in the amount of $\mathrm{C}$ accumulation required for sequestration, this may cause a twofold increase in $C$ reserves in the next 70 years, with the rise in 21$27 \%$ for the RCP4.5 and $16-21 \%$ for the RCP8.5 climate scenario expected in 2020-2040, which is consistent with the previously obtained forecast for Retisols in the Moscow region [22]. Over the next thirty years, the accumulation gradually decreases, amounting to $5-7 \%$ o while maintaining the flow of $C$ to the soil. It reflects the finality of sequestration processes with the onset of a new state of equilibrium. The phenomenon is better pronounced for the RCP8.5 scenario. Simulation demonstrates the prospects of using light-textured soils in the non-Chernozem zone for the implementation of the 4 per 1000 initiative in the long term with no special adjustment of crop rotations and fertilizer system. Organic-mineral fertilizer system has the advantage compared to mineral in SOC stock stability control in the topsoil. However, the increase in C income in the soil under the organo-mineral system cannot increase $\mathrm{C}$ accumulation in the long term due to the low process rate. RothC 26.3 simulation model for the estimation of SOC stock changes in the long-term experiments is suitable for revealing trends in SOM dynamics for future climate conditions. It allows a comparison of the best management practices of fertilization and sustainable crop rotations. Also, it may be used for the selection of the most promising territories for effective control soil ecosystem functions with SOC management.

SOC is traditionally considered as an indicator of anthropogenic impact on ecosystem functions, soil health, and sustainable use as a natural resource [31]. The increase in SOC in poor sandy soils has a positive impact on the biological activity of soils that has a somewhat contradictory effect on soils. On the one hand, it increases soil fertility and soil health; on the other hand, it increases the rate of carbon loss through microbial respiration [32]. Further research is required to improve soil management aimed both on soil health improvement and SOC sequestration.

Author Contributions: Conceptualization, Vladimir Romanenkov; methodology, software, Vladimir Romanenkov, Vera Pavlova, and Stanislav Siptits; investigation, Sergei Lukin and Vladimir Romanenkov; data curation, Igor Ilichev, Vera Pavlova, and Stanislav Siptits; writing-original draft preparation, Igor Ilichev and Vladimir Romanenkov; writing - review and editing, Pavel Krasilnikov; visualization, Igor Ilichev; supervision, project administration, funding acquisition, Pavel Krasilnikov. All authors have read and agreed to the published version of the manuscript.

Funding: The research was a part of the activities of the Horizon 2020 project Coordination of International Research Cooperation on soil CArbon Sequestration in Agriculture (CIRCASA). The financial support for the research was obtained from the project "Management of atmospheric carbon sequestration in arable soils of Russia" of the Federal Task Program "Research and development in priority areas of development of Russia's scientific and technological complex for 2014-2020", unique project identifier RFMEFI61618X0105.

Acknowledgements: This project received technical support from the researchers and technicians of the Faculty of Soil Science of Lomonosov Moscow State University: Dr. Alexey Sorokin, M.S. Anna Kontoboytseva, M.S. Kristina Prokopyeva and M.S. Ilshat Husniev.

Conflicts of Interest: The authors declare no conflict of interest.

\section{References}

1. Hernanz, J.L.; López, R.; Navarrete, L.; Sanchez-Giron, V. Long-term effects of tillage systems and rotations on soil structural stability and organic carbon stratification in semiarid central Spain. Soil and Tillage Research 2002, 66, 129-141. https://doi.org/10.1016/S0167-1987(02)00021-1

2. Lal, R. Soil carbon sequestration impacts on global climate change and food security. Science 2004, 304, 1623-1627. https://science.sciencemag.org/content/suppl/2004/06/09/304.5677.1623.DC1

3. Soussana, J. F.; Lutfalla, S.; Ehrhardt, F.; Rosenstock, T.; Lamanna, C.; Havlík, P.; Richards, M.; Wollenberg, E.; Chotte, J.-L.; Torquebiau, E.; Ciais, P.; Smith, P.; Lal, R. Matching policy and science: Rationale for the '4 
per 1000-soils for food security and climate' initiative. Soil and Tillage Research 2019, 188, 3-15. https://doi.org/10.1016/j.still.2017.12.002

4. Paustian, K.; Lehmann, J.; Ogle, S.; Reay, D.; Robertson, G. P.; Smith, P. Climate-smart soils. Nature 2016, 532(7597), 49-57. https://doi.org/10.1038/nature17174

5. Körschens, M.; Albert, E.; Armbruster, M.; Barkusky, D.; Baumecker, M.; Behle-Schalk, L.; Bischoff, R.; Čergan, Z.; Ellmer, F.; Herbst, F.; Hoffmann, S.; Hofmann, B.; Kismanyoky, T.; Kubat, J.; Kunzova, E.; Lopez-Fando, C.; Merbach, I.; Merbach, W.; Pardor, M.T.; Rogasik, J.; Rühlmann, J.; Spiegel, H.; Schulz, E.; Tajnsek, A.; Toth, Z.; Wegener, H.; Zorn, W. Effect of mineral and organic fertilization on crop yield, nitrogen uptake, carbon and nitrogen balances, as well as soil organic carbon content and dynamics: Results from 20 European long-term field experiments of the twenty-first century. Arch. Agron. Soil Sci. 2013, 59, 1017-1040. https://doi.org/10.1080/03650340.2012.704548

6. Edmeades, D.C. The long-term effects of manures and fertilizers on soil productivity and quality: A review. Nutrient Cycling in Agroecosystems 2003, 66, 165-180. https://doi.org/10.1023/A:1023999816690

7. Maillard, É.; Angers, D. A. Animal manure application and soil organic carbon stocks: A meta-analysis. Global Change Biology 2014, 20, 666-679. https://doi.org/10.1111/gcb.12438

8. Han, P.; Zhang, W.; Wang, G.; Sun, W.; Huang, Y. Changes in soil organic carbon in croplands subjected to fertilizer management: a global meta-analysis. Scientific Reports, 2016, 6, 27199. https://doi.org/10.1038/srep27199

9. Romanenkov, V.; Belichenko, M.; Petrova, A.; Raskatova, T.; Jahn, G.; Krasilnikov, P. Soil organic carbon dynamics in long-term experiments with mineral and organic fertilizers in Russia. Geoderma Regional 2019, 17, paper e00221. https://doi.org/10.1016/j.geodrs.2019.e00221

10. Husniev, I.; Romanenkov, V.; Minakova, O.; Krasilnikov, P. Modelling and prediction of organic carbon dynamics in arable soils based on a 62-year field experiment in the Voronezh Region, European Russia. Agronomy 2020, 10, 1607. https://doi.org/10.3390/agronomy10101607.

11. Prokopyeva, K.O.; Romanenkov, V.A.; Sidorenkova, N.K.; Krasilnikov, P.V. Soil organic carbon sequestration according to two Geoset long-term field experiments in the Moscow region. In E3S Web of Conferences, 2020, 176, 04002. https://doi.org/10.1051/e3sconf /202017604002

12. Romanenkov, V. A., Smith, J. U., Smith, P., Sirotenko, O. D., Rukhovitch, D. I., Romanenko, I. A. Soil organic carbon dynamics of croplands in European Russia: estimates from the "model of humus balance". Regional Environmental Change, 2007, 7, 93-104. https://doi.org/10.1007/s10113-007-0031-7

13. IUSS Working Group WRB. World reference base for soil resources 2014, update 2015: International soil classification system for naming soils and creating legends for soil maps. World Soil Resources Reports No. 106, FAO: Rome, Italy, 2015; 192 pp.

14. Lukin, S.M..; Marchuk E.V.; Zolkina E.I.; Klimkina Y.M. Productivity of grain-row crop rotation under long-term application of different fertilizer systems on sandy loam sod-podzolic soil. Agrochimia 2018, 2, 71-78. (In Russian). https://doi.org/10.7868/S0002188118020060

15. Coleman, K.; Jenkinson, D.S. RothC -26.3 - a model for the turnover of carbon in soil, evaluation of soil organic matter models using existing long-term datasets. Proceedings of the NATO Advanced Research Workshop. NATO ASI Series I. Springer Verlag: Berlin, Germany, 1996; Volume 38, pp. 237-246.

16. Levin, F. I. The amount of plant residues in field crops and its determination by the yield of the main product. Agrochimia 1977, 8, 36-42. (In Russian)

17. Falloon, P.; Smith, P., Coleman, K., Marshall, S. Estimating the size of the inert organic matter pool from total soil organic carbon content for use in the Rothamsted carbon model. Soil Biology \& Biochemistry 1998, 30, 1207-1211. https://doi.org/10.1016/S0038-0717(97)00256-3

18. Smith, P.; Smith, J.U.; Powlson, D.S.; McGill, W.B; Arah, J.R.M.; Chertov, O.G.; Coleman, K.; Franko, U.; Frolking, S.; Jenkinson, D.S.; Jensen, L.S.; Kelly, R.H.; Klein-Gunnewiek, H.; Komarov, A.S.; Li, C.; Molina, J.A.E.; Mueller, T.; Parton, W.J.; Thornley, J.H.M.; Whitmore, A.P. A comparison of the performance of nine soil organic matter models using datasets from seven long-term experiments. Geoderma 1997, 81, 153-225. https://doi.org/10.1016/S0016-7061(97)00087-6

19. IPCC, 2014: Climate Change 2014: Synthesis Report. Contribution of Working Groups I, II and III to the Fifth Assessment Report of the Intergovernmental Panel on Climate Change [Core Writing Team, R.K. Pachauri and L.A. Meyer (eds.)]. IPCC, Geneva, Switzerland, 151 pp. 
20. Second Roshydromet Assessment Report on Climate Change and its Consequences in the Russian Federation. General Summary; Roshydromet, Moscow, Russia, 2014, 54 pp. http://cc.voeikovmgo.ru/ru/publikatsii/2016-03-21-16-23-52 (accessed on 25.11.2020).

21. Pavlova, V.; Shkolnik, I.; Pikaleva, A.; Efimov, S.; Karachenkova, A.; Kattsov, V. Future changes in spring wheat yield in the European Russia as inferred from a large ensemble of high-resolution climate projections. Environ. Res. Lett. 2019, 14, 034010. https://doi.org/10.1088/1748-9326/aaf8be

22. Prokopyeva, K.; Romanenkov, V.; Sidorenkova, N.; Pavlova, V.; Siptits, S.; Krasilnikov, P. The effect of crop rotation and cultivation history on predicted carbon sequestration in soils of two experimental fields in the Moscow region, Russia. Preprints 2020. https://doi.org/

23. Minasny, B.; Malone, B.P.; McBratney, A.B.; Angers, D.A.; Arrouays, D.; Chambers, A.; Chaplot, V.; Chen, Z.-S.; Cheng, K.; Das, B.S.; Field, D.J.; Gimona, A.; Hedley, C.B.; Hong, S.Y.; Mandal, B.I; Marchant, B.P.; Martin, M.; McConkey, B.G.; Mulder, V.L.; O'Rourke, S.; Richer-de-Forges, A.C.; Odeh, I.; Padarian, J.; Paustian, K.; Pan, G.; Poggio, L.; Savin, I.; Stolbovoy, V.; Stockmann, U.; Sulaeman, Y.; Tsui, C.-C.; Vågen, T.-G.; van Wesemael, B.; Winowiecki, L. 2017. Soil carbon 4 per mille. Geoderma 292, 59-86.

24. Chabbi, A.; J. Lehmann, P.; Ciais, H.W.; Loescher, M.F.; Cotrufo, A.; Don, M.; SanClements, L.; Schipper, L.; Six, J.; Smith, P.; Rumpel, C. Aligning agriculture and climate policy. Nature Climate Change 2017, 7, 307309. https://doi.org/10.1038/nclimate3286

25. Ražauskaite, R.; Vanguelova, E.; Cornulier, T.; Smith, P.; Randle, T.; Smith, J.U. A new approach using modeling to interpret measured changes in soil organic carbon in forests; the case of a 200 year pine chronosequence on a podzolic soil in Scotland. Front. Environ. Sci. 2020, 8, 527549. https://doi.org/ 10.3389/fenvs.2020.527549

26. Wang, G.; Luo, Z.; Han, P.; Chen, H.; Xu, J. Critical carbon input to maintain current soil organic carbon stocks in global wheat systems. Scientific Reports 2016, 6. https://doi.org/10.1038/srep19327

27. Poulton, P.; Johnston, J.; Macdonald, A; White, R.; Powlson, D. Major limitations to achieving “4 per 1000” increases in soil organic carbon stock in temperate regions: Evidence from long-term experiments at Rothamsted Research, United Kingdom. Global Change Biology 2018, 24, 2563-2584. https://doi.org/10.1111/gcb.14066

28. Wiesmeier, M.; Poeplau, C.; Sierra, C.A.; Maier, H.; Frühauf, C.; Hübner, R.; Kühnel, A.; Spörlein, P.; Geuß, U.; Hangen, E.; Schilling, B.; von Lützow, M.; Kögel-Knabner, I. Projected loss of soil organic carbon in temperate agricultural soils in the 21st century: effects of climate change and carbon input trends. Sci. Rep. 2016, 6, 32525. https://doi.org/10.1038/srep32525

29. Grant, R. F.; Juma, N. G.; Robertson, J. A.; Izaurralde, R. C.; McGill, W. B. Long-term changes in soil carbon under different fertilizer, manure, and rotation: testing the mathematical model Ecosys with data from the Breton Plots. Soil Sci. Soc. Am. J. 2001,65, 205-214. https://doi.org/10.2136/sssaj2001.651205x

30. Ludwig, B; John, B.; Ellerbrock, R.; Kaiser, M; Flessa, H. Stabilization of carbon from maize in a sandy soil in a long-term experiment. Eur. J. Soil Sci. 2003, 54,117-126. https://doi.org/10.1046/j.1365-2389.2003.00496.x

31. Campbell E.E.; Paustian, K. Current developments in soil organic matter modeling and the expansion of model applications: a review. Environ. Res. Lett. 2015, 10, 123004. https://doi.org/10.1088/17489326/10/12/123004

32. Thangarajan, R.; Bolan, N.S.; Tian, G.; Naidu, R.; Kunhikrishnan, A. Role of organic amendment application on greenhouse gas emission from soil. Sci. Total Environ. 2013, 465, 72-96. https://doi.org/10.1016/j.scitotenv.2013.01.031 